\title{
Design AND IMPRovement of Production PROCESSES
}

\author{
MicietA, B. \& StOllmann, V.
}

Abstract: The article deals with new trends in the improvement of production and logistics processes. In the first part, the article deals with the importance of improvement of processes. Reduction of costs represents a very important factor in increasing the competitiveness of companies in a sector with strong competition. Planning and controlling of processes enables responding to condition in the market in a short period of time. In the second part of the article, an approach used in improvement of production processes will be described. In the third part, the authors refer to new and perspective methods focused mainly on the line balancing used in their department as well as to contributions in this field. In the last part, new ways in the improvement of production processes will be described.

Key words: balancing, assembly, digital factory, operation costs
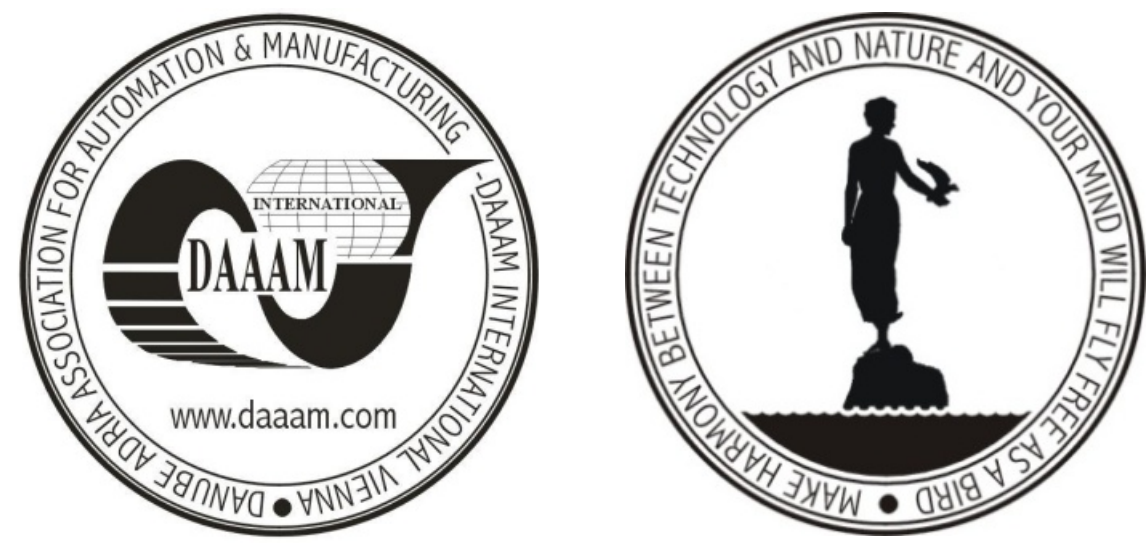

Authors' data: Univ.Prof. Dipl.-Ing. Micieta, B[ranislav]; Dipl.-Ing. Stollmann, V[ladimir], University of Zilina, Univerzitna 8215/1, 010 26, Zilina, Slovakia, branislav.micieta@fstroj.uniza.sk, Vladimir.stollmann@fstroj.uniza.sk

This Publication has to be referred as: Micieta, $B$ [ranislav] \& Stollmann, V[ladimir] (2009). Design and Improvement of Production Processes, Chapter 41 in DAAAM International Scientific Book 2009, pp. 397-404, B. Katalinic (Ed.), Published by DAAAM International, ISBN 978-3-901509-69-8, ISSN 1726-9687, Vienna, Austria

DOI: 10.2507/daaam.scibook.2009.41 